\title{
Influence of Grit Size and Wood Species on the Granularity of Dust Particles during Sanding
}

\author{
Marta Pędzik ${ }^{1,2} \mathbb{D}$, Kinga Stuper-Szablewska ${ }^{3}$, Maciej Sydor ${ }^{4}\left(\mathbb{C}\right.$ and Tomasz Rogoziński ${ }^{1, *(1)}$ \\ 1 Department of Furniture Design, Faculty of Forestry and Wood Technology, Poznań University \\ of Life Sciences, 60-627 Poznań, Poland; marta.pedzik@itd.lukasiewicz.gov.pl \\ 2 Wood-Based Products and Biocomposites Department, Łukasiewicz Research Network, \\ Wood Technology Institute, 60-654 Poznań, Poland \\ 3 Department of Chemistry, Faculty of Forestry and Wood Technology, Poznań University of Life Sciences, \\ 60-625 Poznań, Poland; kinga.stuper@up.poznan.pl \\ 4 Department of Woodworking Machines and Fundamentals of Machine Design, Faculty of Forestry and \\ Wood Technology, Poznań University of Life Sciences, 60-627 Poznań, Poland; maciej.sydor@up.poznan.pl \\ * Correspondence: tomasz.rogozinski@up.poznan.pl
}

Received: 28 October 2020; Accepted: 16 November 2020; Published: 18 November 2020

\begin{abstract}
Wood dust poses a threat to the health of employees and the risk of explosion and fire, accelerates the wear of machines, worsens the quality of processing, and requires large financial outlays for its removal. The aim of this study was to investigate the extent to which the grit size of sandpaper influences the size of the wood dust particles and the proportion of the finest particles which, when dispersed in the air, may constitute the respirable fraction. Six species of hardwood (beech, oak, ash, hornbeam, alder, and walnut), and three species of softwood (larch, pine, and spruce) were used in the research. While sanding the samples under the established laboratory conditions, the following were measured for two types of sandpapers (grit sizes P60 and P180): mean arithmetic particle size of dust and finest dust particles content $(<10 \mu \mathrm{m})$. Based on the obtained results, we found that the largest dust particle sizes were obtained for alder, pine, and spruce; the smallest size of dust particles during sanding with both sandpapers was obtained for beech, hornbeam, oak, ash, larch, and walnut. The mean arithmetic particle sizes ranged from $327.98 \mu \mathrm{m}$ for pine to $104.23 \mu \mathrm{m}$ for hornbeam. The mean particle size of the dust obtained with P60 granulation paper was 1.4 times larger than that of the dust obtained with P180 granulation sandpaper. The content of the finest dust particles ranged from $0.21 \%$ for pine (P60 sandpaper) to $12.58 \%$ for beech (P180 sandpaper).The type of wood (hardwood or softwood) has a significant influence on the particle size and the content of the finest dust fraction.
\end{abstract}

Keywords: wood dust; sanding; sandpaper; particle-size distribution

\section{Introduction}

Wood dust is a waste generated during mechanical wood processing in wood industry plants. Dust poses a threat to workers health, increases the risk of explosion and fire, accelerates the wear of machines, worsens the quality of processing, and incurs high costs for its removal.

Dust with particles smaller than $10 \mu \mathrm{m}$ affects the respiratory system, eyes, and skin, causing health effects in the form of irritation, allergies, and diseases [1-6]. The dust toxicity is determined to a large extent by the type of wood raw material, which results from the different contents of the main chemical components, such as cellulose, hemicellulose, and lignin in coniferous and deciduous trees $[7,8]$. Long-term inhalation of air polluted with wood dust, including the most harmful (i.e., beech and oak wood) may contribute to cancer incidence. As a result, wood dust was classified by the International 
Agency for Research on Cancer (IARC) among the most dangerous and carcinogenic materials for humans. According to Directive 2004/37/EC of the European Parliament and of the Council of 29 April 2004 on the protection of workers against the risks related to exposure to carcinogens or mutagens at work; its current limit is $3 \mathrm{mg} / \mathrm{m}^{3}$. After 17 January 2023, it will be reduced to only $2 \mathrm{mg} / \mathrm{m}^{3}$. To meet such high requirements, it will be necessary to use all available technical means of dust reduction.

The dustiness of the air inside production plants causes a fire and explosion hazard. Dust dispersed in the air can create an explosive mixture and settle on walls, floors, and machines, creating a risk of fire and explosion at the workplace. The inflammability of wood dust favors the spread of fire [9-13].

Extraction devices designed to remove dust from processing areas are never completely effective, especially in relation to the very small-sized dust particles. One way to reduce the amount of fine dust generated is to reduce the thickness of the furniture components and thus the diameters and depths of the holes for connectors, which reduces the volume of wood material cut. Such a procedure is effective in eliminating drilling and milling operations; however, it requires the development of new furniture fasteners [14] and does not reduce the need for sanding operations. Another way is to adjust the processing parameters to the type and properties of the material being processed. Appropriate adjustment of the treatment parameters will result in the formation of a reduced amount of fine dust dispersed in the air, could constitute a potentially dangerous inhaled fraction.

With regards to sawing and milling, the technological parameters of the processing, as well as the type and sharpness of the tools used, are particularly important. Among technological parameters, the feed per tooth, the feed rate, and the thickness of the cut layer have important influences on the amount and size of the created dust particles [15-25].

The largest amount of dust is generated during the sanding of wood; therefore, this technological operation is considered to be the source of the most serious hazards related to wood dust. The amount and size of the dust particles created when sanding wood depends on the type of sanding machine used: wide-belt, narrow-belt, or disc sanders. It is difficult to remove the dust from some special types of sanding machines, such as manual belts, discs, and oscillating sanders [26,27].

Recent studies on the size of the dust particles created during the sanding of wood concerned some of the most commonly used wood species in the industry. These tests were carried out using various types of sanding machines and sandpapers with grain sizes typical for the basic technical requirements of sanding operations. Many times, the sandpaper type studied was limited to paper tapes with the grain size of P80. Due to the method of sieve analysis used in these studies to assess the size of dust particles (the sieve with the smallest mesh of $32 \mu \mathrm{m}$ ), it was not possible to quantify the content of dust particles with the smallest sizes, which would constitute the respirable fraction after dispersion in the air [28-30]. Such particles are present in the wood sanding dust. Their presence was confirmed by spectrometric, optical, and laser methods [27,28]; however, no comprehensive and comparative studies have been performed on the content of wood dust particles that would be small enough to be dispersed in the air as a thoracic fraction [31-33].

To reduce the risk to workers' health, increase work safety, and meet future legal requirements for fine wood dust, we examined the most important factor characterizing the sanding process of wood-grit size. Therefore, the aim of the study was to investigate the extent to which the grit size of the sandpaper affects the size of the dust particles created during sanding different wood species and the proportion of the finest particles, which, when dispersed in the air, may constitute a respirable fraction.

\section{Materials and Methods}

\subsection{Sanding and Particle Size Analysis}

Three species of softwood and six species of hardwood often used in the wood industry were used in this research (Table 1). The densities of wood species were determined according to the method described in the standard ISO 13061-2:2014. 
Table 1. Wood species.

\begin{tabular}{cccccccccc}
\hline Wood Species & Beech & Oak & Ash & Hornbeam & Alder & Walnut & Larch & Pine & Spruce \\
\hline Density, $\mathrm{kg} / \mathrm{m}^{-3}$ & 687 & 686 & 621 & 754 & 446 & 641 & 546 & 453 & 420 \\
\hline
\end{tabular}

Sanding was performed using a prototype narrow belt sanding machine designed and made in the laboratory of the Department of Furniture Design (Faculty of Forestry and Wood Technology, Poznań University of Life Sciences PULS, Poznań, Poland). EKA 1000 F sandpaper (Ekamant, Poznań, Poland) in the form of belts with dimensions $1000 \times 80 \mathrm{~mm}$ was used (Figure 1). The grit sizes of the paper were P60 and P180. A cutting speed of $14.5 \mathrm{~m} / \mathrm{s}$ and a sanding pressure of $0.65 \mathrm{~N} / \mathrm{cm}^{2}$ were applied.

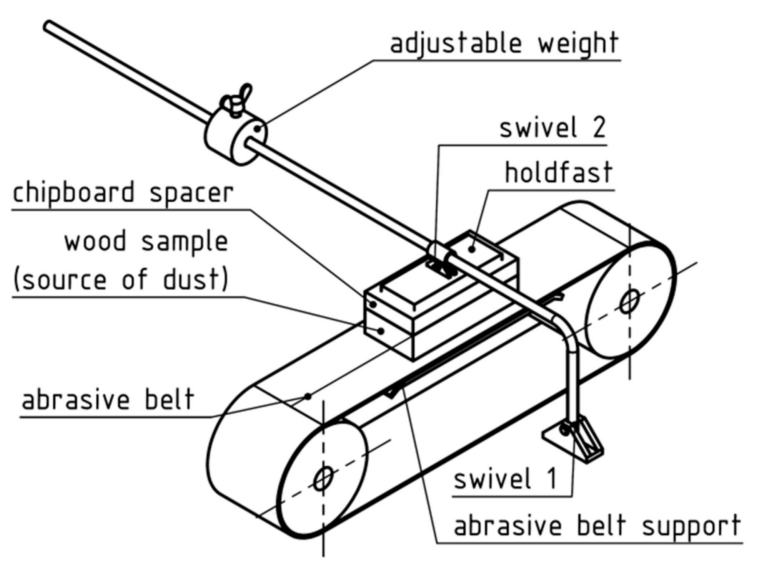

Figure 1. Schematic diagram of sanding.

Particle-size determination and calculation of the content of fine dust particles (the content of particles $<10 \mu \mathrm{m}$ ) were carried out according to methods described by $[20,22,34,35]$. In the sieve analysis, a set of sieves with aperture sizes of 250,125 , and $63 \mu \mathrm{m}$ was used due to the high level of wood dust fineness. Then, the content of the dust particles $<10 \mu \mathrm{m}$ in the sieve fraction $<63 \mu \mathrm{m}$ was measured using a Analysette 22 MicroTec Plus laser particle sizer (Fritsch, Idar-Oberstein, Germany). Based on the results of sieve analysis, the cumulative particle size distribution $\mathrm{Q}_{3}$ and the particle mean arithmetic diameter $\bar{x}$ was calculated as follows:

$$
\begin{aligned}
& Q_{3}=\sum_{i=1}^{n} \bar{q}_{3, i} \Delta x_{i} \\
& \bar{x}=\sum_{i=1}^{n} x_{i} \times q_{3 i}
\end{aligned}
$$

where $q_{3}$ is the particle size distribution by mass, $x$ is the mean value of particle size class, and $n$ is the number of particle size classes.

\subsection{Statistical Analysis}

The results recorded in the course of conducted tests were subjected to statistical analysis with the use of STATISTICA ver. 13.1 (StatSoft, Inc., Tulsa, OK, USA) and Microsoft ${ }^{\circledR}$ Excel 2020, Microsoft 365 (Addinsoft, Inc., Brooklyn, NY, USA) software packages. In order to compare grit sizes of the P60 and P180 sandpaper, multivariate comparison procedure was used, with identical letters denoting a lack of differences at the significance level of $P=0.05$, lowercase letters denote significant differences between the grit sizes of the sandpaper, and uppercase letters denote significant differences between wood species. Correlation coefficients between the wood density and the mean arithmetic particle size of 
dust were calculated. The multiplicity factors for the mean arithmetic particle size and for the content of the finest particles obtained from paper with the grit sizes P60 to P180 were calculated. Moreover, a step linear discriminatory analysis (SLDA) and the principal component analysis (PCA) were used to separate groups of analyzed dust in the entire population.

\section{Results and Discussion}

The basic results of the particle size analysis came from the sieve analysis. The cumulative distributions (Figure 2) showed that, in general, the dust from sanding operations performed with the use of P180 sandpaper is finer than dust created in sanding with P60 sandpaper.

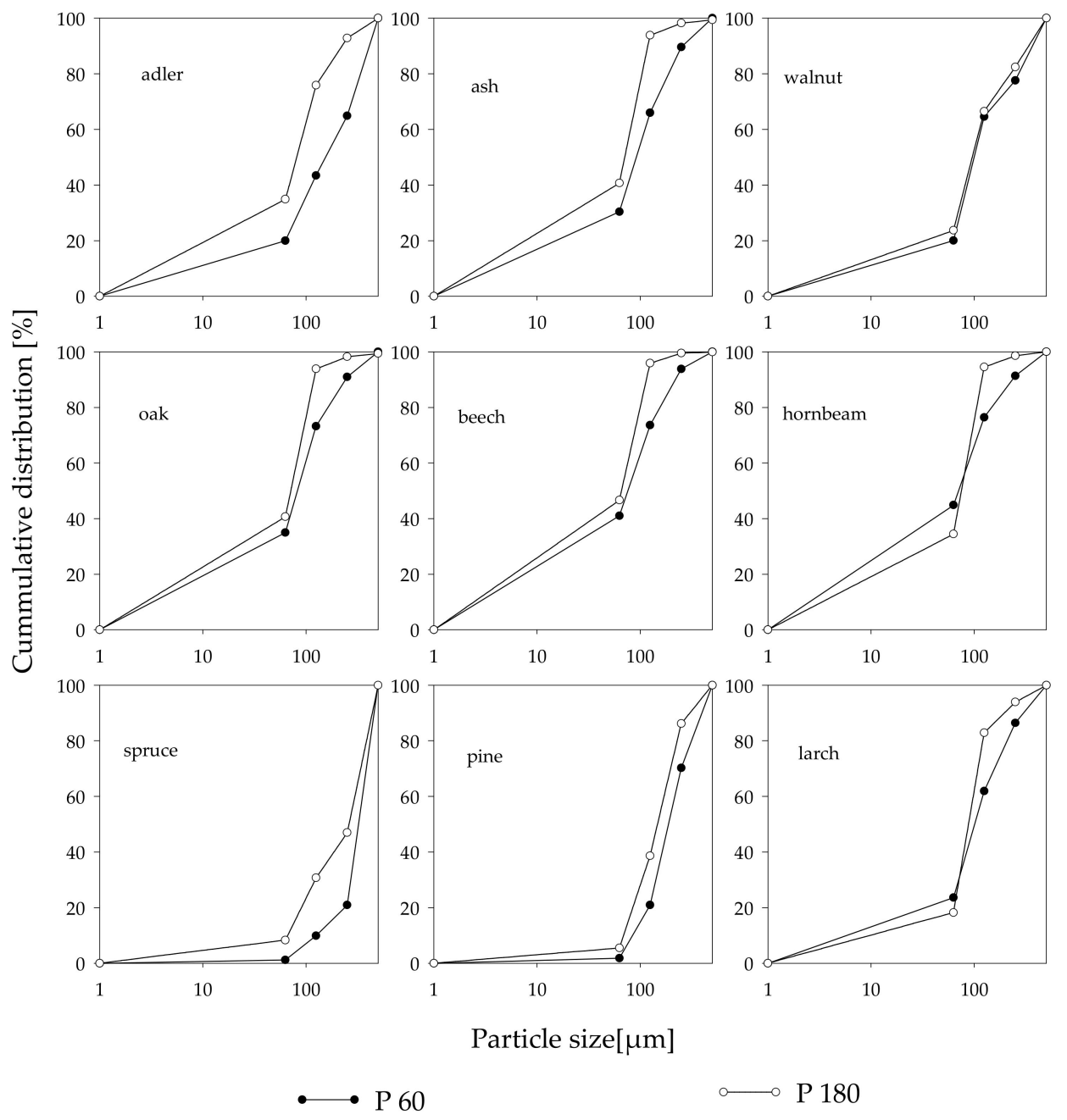

Figure 2. Particle size distributions of wood dust.

To compare the mean arithmetic particle sizes of dust created in sanding with P60 and P180 sandpapers within the entire population, that is, between wood species and within wood species, multivariance analysis was used (Figure 3). On the basis of the obtained results, the smallest size of dust particles created during sanding with both sandpapers was found for beech, hornbeam, oak, ash, larch, and walnut. Significantly larger sizes of dust were obtained for alder, pine, and spruce. By analyzing the ratio of mean arithmetic particle sizes of dust obtained from paper with grit sizes P60 and P180, the multiplicity factors were calculated and we found that the average for the entire population was 1.4, which means that the mean particle size of dust obtained from the paper with grit size P60 was 1.4 times higher than that of dust obtained from paper with the grit size P180. When analyzing the dust 
from hardwood and softwood species separately, we found that the multiplicity factors were 1.4 and 1.3 , respectively. The lowest multiplication factor was found for walnut wood, at 1.1, and the highest for alder wood, at 1.8 .

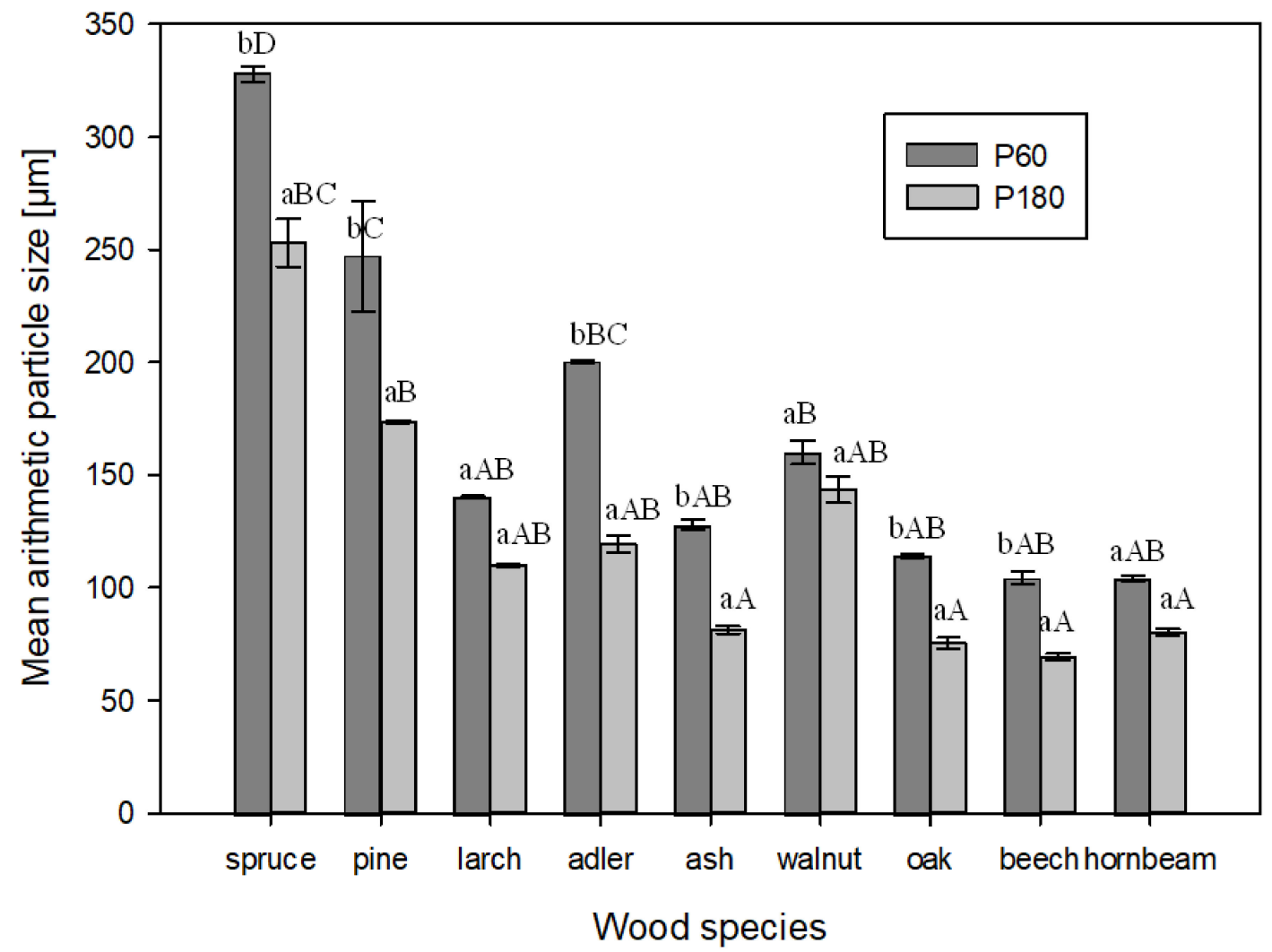

Figure 3. Analysis of the mean arithmetic particle sizes of dust; $a$, b: the same letters indicate no significant differences at the significance level of 0.05 between sandpaper grit size; A, B: the same letters indicate no significant differences at a significance level of 0.05 between wood species.

While analyzing the content of the finest particles $(<10 \mu \mathrm{m})$, a multivariate analysis was also performed to compare this content for wood dust created during sanding with papers of grit sizes P60 and P180 for different species of wood and to compare the content of particles $<10 \mu \mathrm{m}$ within species (Figure 4). There were no significant differences between the content of the finest dust particles obtained from sanding with both sandpapers for pine and larch. When analyzing the differences for the species, significantly higher contents of the smallest particles were found for alder, walnut, oak, beech, and hornbeam. By analyzing the ratio of dust particles $<10 \mu \mathrm{m}$ obtained from sandpaper of grit size P60 to the paper of grit size P180, the multiplicity factors were also calculated and an analogous tendency was found for the mean arithmetic particle size. The average multiplicity factor P60/P180 was 1.4 for the entire population of wood species tested.

Then, we analyzed the main components on the basis of the value of the mean arithmetic particles sizes and the content of the finest particles for both grit sizes of sandpaper, and the second predictor, next to the wood species (Factor 1), was indicated as the type (hardwood or softwood) of wood (Factor 2). Supplementing the grouping factors with this factor showed that the obtained results could be divided into two groups, as shown in Figure 5. One region of the loop comprises hardwood and the other, softwood. The full separation was obtained by a factor of two. This clear division was also confirmed by the PCA result showing the projection of the variables on the plane (Figure 6). 


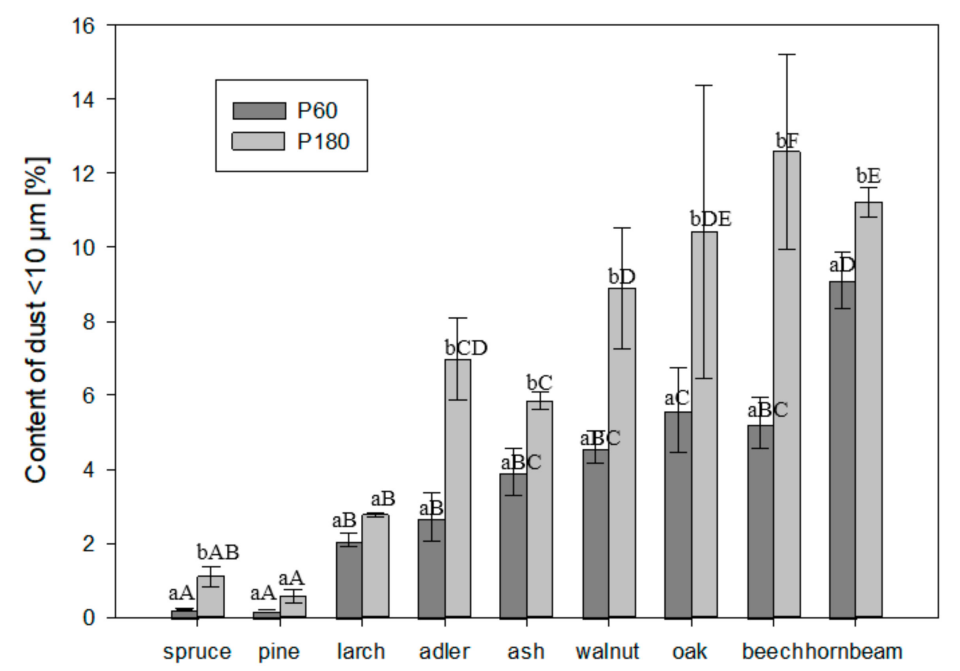

Figure 4. Analysis of the content of the finest dust particles; $a$, b: the same letters indicate no significant differences at the significance level of 0.05 between sandpaper grit sizes; A, B: the same letters indicate no significant differences at a significance level of 0.05 between wood species.

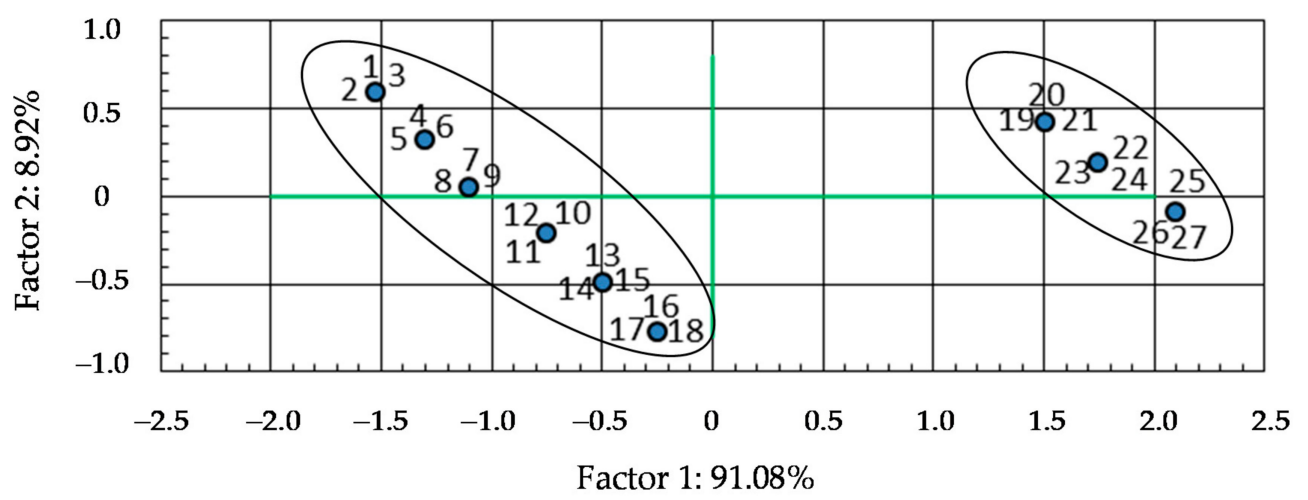

Figure 5. The spread of the mean arithmetic particle size of dust and the content of the finest particles. $(1,2,3$ are beech; 4, 5, 6 are oak; 7, 8, 9 are hornbeam; 10,11, 12 are ash; $13,14,15$ are alder; 16, 17, 18 are walnut; 19, 20, 21 are larch; 22, 23, 24 are pine; and 25, 26, 27 are spruce) based on the multiplicity factor of the mean arithmetic particle size of the dust created in sanding with sandpapers of grit sizes P60 and P180 and on the content of the finest particles. The clusters of results that form separate populations are marked in the loops.

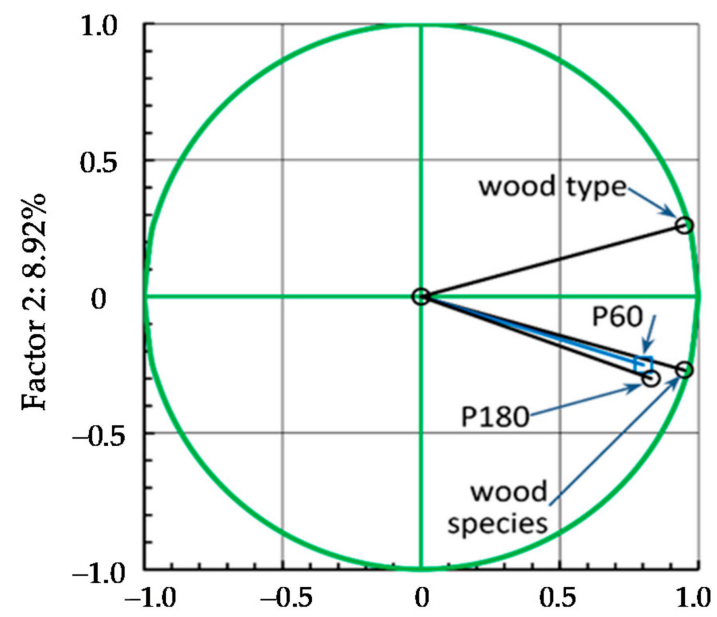

Figure 6. The result of principal component analysis (PCA) for the entire population of dust. 
The correlation coefficients between the wood density and the mean arithmetic particle size of dust were calculated. Very high values of these coefficients for the tested wood species were found at the level of 0.9588 for grit size P60 and 0.8794 for grit size P180 based on this analysis. A similar relationship was found for particles $<10 \mu \mathrm{m}$. The correlation coefficient value was 0.9227 for the P60 grit size and 0.8812 for the P180 grit size. This confirms the highly significant relationship between the grit size of sandpaper and the mean arithmetic particle size and the content of the finest particles in wood dust.

The share of beech wood dust particles with a diameter of $\leq 80 \mu \mathrm{m}$ in the range of $89.21-96.29 \%$ was described by Očkajová et al. [18]. The finest dust particles that can be found in a such large proportions of small particles are undesirable in working environments. They can penetrate the alveoli and be the source of serious diseases. A similar relationship was obtained when using P180 paper, where the share of this fraction was also significant.

The wood species also has a significant impact on the sanding belt wear. This is due to the specific, mainly microscopic, structure of the wood, as well as different physical and mechanical properties. Beech wood has a uniform structure in spring-summer rings and scattered rings. Oak wood has significant differences in density between spring and summer rings, as well as a relatively high share of extractive substances, even up to 6.1\% [36]. Softwood, such as coniferous species, has relatively long fibers, which result in a fraction with larger particles.

\section{Conclusions}

Based on these studies, we concluded that: The largest mean arithmetic dust particle sizes were obtained for alder, pine, and spruce. The smallest mean arithmetic dust particle sizes were obtained for beech, hornbeam, oak, ash, larch, and walnut. The highest content of the finest particles was found for alder, walnut, oak, beech, and hornbeam. The type of wood (hardwood or softwood) has a significant influence on the mean arithmetic dust size and the content of the dust fraction with the size $<10 \mu \mathrm{m}$. The particle size analyses of dust from the sanding of different wood species showed that the sanding of walnut, oak, beech, and hornbeam can be a source of a considerable amount of very fine dust particles, which can from a respirable fraction when dispersed in the air.

Author Contributions: Conceptualization, M.S. and T.R.; Data curation, M.P. and K.S.-S.; Formal analysis, M.S.; Funding acquisition, M.S.; Investigation, M.P. and K.S.-S.; Methodology, M.P. and T.R.; Project administration, M.S. and T.R.; Resources, T.R.; Software, K.S.-S.; Supervision, T.R.; Validation, M.S.; Visualization, K.S.-S.; Writing, original draft, T.R.; Writing, review and editing, M.S. All authors have read and agreed to the published version of the manuscript.

Funding: The article processing charge (APC) was financed within the European project POIR.01.02.00-00-00102/17, "The first Polish innovative universal system of furniture fasteners for joining various wood and wood-composite materials in the furniture industry", implemented by Digitouch sp. z o.o. (Suchy Las, Poland). The project is a part of the Polish sectoral programme WoodINN financed by the Polish National Centre for Research and Development (NCRD).

Conflicts of Interest: The authors declare no conflict of interest.

\section{References}

1. Douwes, J.; McLean, D.; Slater, T.; Pearce, N. Asthma and Other Respiratory Symptoms in New Zealand Pine Processing Sawmill Workers. Am. J. Ind. Med. 2001, 39, 608-615. [CrossRef] [PubMed]

2. Schlunssen, V. Asthma and Other Respiratory Diseases among Workers in the Furniture Industry Occupationally Exposed to Wood Dust. Dan. Med. Bull. 2001, 48, 191.

3. Schlünssen, V.; Sigsgaard, T.; Raulf-Heimsoth, M.; Kespohl, S. Workplace Exposure to Wood Dust and the Prevalence of Wood-Specific Sensitization. Allergol. Sel. 2018, 2, 101. [CrossRef] [PubMed]

4. Mračková, E.; Krišt'ák, L'; Kučerka, M.; Gaff, M.; Gajtanska, M. Creation of Wood Dust during Wood Processing: Size Analysis, Dust Separation, and Occupational Health. BioResources 2016, 11, $209-222$. [CrossRef] 
5. Asgedom, A.A.; Bråtveit, M.; Moen, B.E. High Prevalence of Respiratory Symptoms among Particleboard Workers in Ethiopia: A Cross-Sectional Study. Int. J. Environ. Res. Public Health 2019, 16, 2158. [CrossRef]

6. Tureková, I.; Mračková, E.; Marková, I. Determination of Waste Industrial Dust Safety Characteristics. Int. J. Environ. Res. Public Health 2019, 16, 2103. [CrossRef]

7. Jacobsen, G.; Schaumburg, I.; Sigsgaard, T.; Schlünssen, V. Non-Malignant Respiratory Diseases and Occupational Exposure to Wood Dust. Part II. Dry Wood Industry. Ann. Agric. Environ. Med. 2010, 17, $29-44$.

8. Lorincová, S.; Hitka, M.; Čambál, M.; Szabó, P.; Javorčíková, J. Motivation Factors Influencing Senior Managers in the Forestry and Wood-Processing Sector in Slovakia. BioResources 2016, 11, 10339-10348. [CrossRef]

9. Igaz, R.; Kminiak, R.; Krišt'ák, L'.; Němec, M.; Gergel', T. Methodology of Temperature Monitoring in the Process of CNC Machining of Solid Wood. Sustainability 2019, 11, 95. [CrossRef]

10. Marková, I.; Mračková, E.; Očkajová, A.; Ladomerský, J. Granulometry of selected wood dust species of dust from orbital sanders. Wood Res. 2016, 61, 983-992.

11. Marková, I.; Ladomerský, J.; Hroncová, E.; Mračková, E. Thermal Parameters of Beech Wood Dust. BioResources 2018, 13, 3098-3109. [CrossRef]

12. Mračková, E.; Tureková, I. The Dimensional Characteristics of the Particles of Wood Dust of Selected Deciduous Trees Considering to Explosion. Key Eng. Mater. 2016, 688, 182-189. [CrossRef]

13. Tureková, I.; Marková, I. Ignition of Deposited Wood Dust Layer by Selected Sources. Appl. Sci. 2020, 10, 5779. [CrossRef]

14. Branowski, B.; Starczewski, K.; Zabłocki, M.; Sydor, M. Space for Innovation in the Design of Furniture Fasteners. BioResources 2020, 15, 8472-8495. [CrossRef]

15. Lučić, R.B.; Kos, A.; Antonović, A.; Vujasinović, E.; Šimičić, I. Properties of Chipped Wood Generated during Wood Processing. Drv. Ind. 2005, 1, 11-19.

16. Dzurenda, L.; Kucerka, M. Change in Structure of Granularity and Aeromechanical Characteristics of Wet Spruce Sawdust in the Process of Drying. Ann. Wars. Agric. Univ. For. Wood Technol. 2005, 56, 230-236.

17. Dzurenda, L.; Wasielewski, R.; Orłowski, K. Granulometric Analysis of Dry Sawdust from the Sawing Process on the Frame Sawing Machine PRW15M = Granulometrická Analýza Suchej Piliny z Procesu Pílenia Borovicového Dreva Na Rámovej Píle PRW-15M. Acta Fac. Xylologiae Zvolen 2006, 48, 51-57.

18. Očkajová, A.; Stebila, J.; Rybakowski, M.; Rogozinski, T.; Krišták, L.; L'uptáková, J. The Granularity of Dust Particles When Sanding Wood and Wood-Based Materials. Adv. Mater. Res. 2014, 1001, 432-437. [CrossRef]

19. Očkajová, A.; Kučerka, M.; Banski, A.; Rogoziński, T. Factors Affecting the Granularity of Wood Dust Particles. Chip Chipless Woodwork. Process. 2016, 10, 137-144.

20. Hlásková, L.; Rogoziński, T.; Kopecký, Z. Influence of Feed Speed on the Content of Fine Dust during Cutting of Two-Side-Laminated Particleboards. Drv. Ind. 2016, 67, 9-15. [CrossRef]

21. Pałubicki, B.; Rogoziński, T. Efficiency of Chips Removal during CNC Machining of Particleboard. Wood Res. 2016, 61, 811-818.

22. Piernik, M.; Rogoziński, T.; Krauss, A.; Pinkowski, G. The Influence of the Thermal Modification of Pine (Pinus Sylvestris L.) Wood on the Creation of Fine Dust Particles in Plane Milling: Fine Dust Creation in the Plane Milling of Thermally Modified Pine Wood. J. Occup. Health 2019, 61, 481-488. [CrossRef] [PubMed]

23. Dzurenda, L.; Orlowski, K.; Grzeskiewicz, M. Effect of Thermal Modification of Oak Wood on Sawwdust Granularity. Drv. Ind. 2010, 61, 89-94.

24. Hlaskova, L.; Rogozinski, T.; Dolny, S.; Kopecky, Z.; Jedinak, M. Content of Respirable and Inhalable Fractions in Dust Created While Sawing Beech Wood and Its Modifications. Drew. Pr. Nauk. Doniesienia Komun. 2015, 58, 135-146. [CrossRef]

25. Korčok, M.; Koleda, P.; Barcík, Š.; Očkajová, A.; Kučerka, M. Effect of Technological and Material Parameters on Final Surface Quality of Machining When Milling Thermally Treated Spruce Wood. Bioresources 2019, 14, 10004-10013. [CrossRef]

26. Očkajová, A.; Kučerka, M. Granularity of Dust Particles Obtained in the Process of Sanding and Milling of Particleboard. Woodwork. Tech. 2011, 4, 211-217.

27. Očkajová, A.; Kučerka, M.; Krišt'ák, L.; Igaz, R. Granulometric Analysis of Sanding Dust from Selected Wood Species. BioResources 2018, 13, 7481-7495. [CrossRef] 
28. Kminiak, R.; Orlowski, K.A.; Dzurenda, L.; Chuchala, D.; Banski, A. Effect of Thermal Treatment of Birch Wood by Saturated Water Vapor on Granulometric Composition of Chips from Sawing and Milling Processes from the Point of View of Its Processing to Composites. Appl. Sci. 2020, 10, 7545. [CrossRef]

29. Očkajová, A.; Kučerka, M.; Kminiak, R.; Krišták, L'.; Igaz, R.; Réh, R. Occupational Exposure to Dust Produced When Milling Thermally Modified Wood. Int. J. Environ. Res. Public Health 2020, 17, 1478. [CrossRef]

30. Mazzoli, A.; Favoni, O. Particle Size, Size Distribution and Morphological Evaluation of Airborne Dust Particles of Diverse Woods by Scanning Electron Microscopy and Image Processing Program. Powder Technol. 2012, 225, 65-71. [CrossRef]

31. Welling, I.; Lehtimäki, M.; Rautio, S.; Lähde, T.; Enbom, S.; Hynynen, P.; Hämeri, K. Wood Dust Particle and Mass Concentrations and Filtration Efficiency in Sanding of Wood Materials. J. Occup. Environ. Hyg. 2008, 6, 90-98. [CrossRef]

32. Aro, M.D.; Geerts, S.M.; French, S.; Cai, M. Particle Size Analysis of Airborne Wood Dust Produced from Sawing Thermally Modified Wood. Eur. J. Wood Wood Prod. 2019, 77, 211-218. [CrossRef]

33. Beljo-Lučić, R.; Čavlović, A.O.; Jug, M. Definitions and Relation of Airborne Wood Dust Fractions. In Proceedings of the International Science Conference: Woodworking techniques, Prague, Czech Republic, 7-10 September 2011; pp. 25-32.

34. Rogoziński, T.; Wilkowski, J.; Gorski, J.; Czarniak, P.; Podziewski, P.; Szymanowski, K. Dust Creation in CNC Drilling of Wood Composites. Biorecources 2015, 10, 3657-3665. [CrossRef]

35. Rogoziński, T.; Wilkowski, J.; Górski, J.; Szymanowski, K.; Podziewski, P.; Czarniak, P. Fine Particles Content in Dust Created in CNC Milling of Selected Wood Composites. Wood Fiber Sci. 2017, 49, 461-469.

36. Očkajová, A.; Kučerka, M.; Krišták, L.; Ružiak, I.; Gaff, M. Efficiency of Sanding Belts for Beech and Oak Sanding. BioResources 2016, 11, 5242-5254. [CrossRef]

Publisher's Note: MDPI stays neutral with regard to jurisdictional claims in published maps and institutional affiliations. 